\title{
Sea surface salinity and temperature in the southern Atlantic Ocean from South African icebreakers, 2010-2017
}

\author{
Giuseppe Aulicino $^{1,2}$, Yuri Cotroneo ${ }^{2}$, Isabelle Ansorge ${ }^{3}$, Marcel van den Berg ${ }^{4}$, Cinzia Cesarano ${ }^{5}$, \\ Maria Belmonte Rivas ${ }^{6,7}$, and Estrella Olmedo Casal ${ }^{6}$ \\ ${ }^{1}$ Department of Life and Environmental Sciences, Università Politecnica delle Marche, Ancona, 60131, Italy \\ ${ }^{2}$ Department of Science and Technologies, Università degli Studi di Napoli Parthenope, Naples, 80143, Italy \\ ${ }^{3}$ Marine Research Institute, Oceanography Department, University of Cape Town, \\ Rondebosch, Cape Town, 7701, South Africa \\ ${ }^{4}$ Department of Environmental Affairs, Cape Town, 8001, South Africa \\ ${ }^{5}$ Progetto Terra, Gragnano, 80054, Italy \\ ${ }^{6}$ Institute of Marine Sciences, ICM, Barcelona, 08003, Spain \\ ${ }^{7}$ Royal Netherlands Meteorological Institute, KNMI, De Bilt, 3730, the Netherlands \\ Correspondence: Giuseppe Aulicino (g.aulicino@staff.univpm.it)
}

Received: 23 March 2018 - Discussion started: 3 April 2018

Revised: 19 June 2018 - Accepted: 22 June 2018 - Published: 5 July 2018

\begin{abstract}
We present here sea surface salinity (SSS) and temperature (SST) data collected on board the S.A. Agulhas-I and S.A. Agulhas-II research vessels, in the framework of the South African National Antarctic Programme (SANAP). Onboard Sea-Bird thermosalinographs were regularly calibrated and continuously monitored in-between cruises, and no appreciable sensor drift emerged. Water samples were taken on a daily basis and later analyzed with a Portasal salinometer; some CTD measurements collected along the cruises were used to validate the data. No systematic differences appeared after a rigorous quality control on continuous data. Results show that salinity measurement error was a few hundredths of a unit on the practical salinity scale. Quality control included several steps, among which an automatic detection of unreliable values through selected threshold criteria and an attribution of quality flags based on multiple criteria, i.e., analysis of information included in the cruise reports, detection of insufficient flow and/or presence of air bubbles and ice crystals in the seawater pipe, visual inspection of individual campaigns, and ex post check of sea ice maps for confirming ice field locations. This data processing led us to discard about $36 \%$ of acquired observations, while reliable data showed an excellent agreement with several independent SSS products. Nevertheless, a sea ice flag has been included for identifying valid data which could have been affected by scattered sea ice contamination. In our opinion, this dataset, available through an unrestricted repository at https://doi.org/10.7289/V56M3545, contributes to improving the knowledge of surface water features in one of the most important regions for global climate. The dataset will be highly valuable for studies focusing on climate variability in the Atlantic sector of the Southern Ocean, especially across the Antarctic Circumpolar Current and its fronts. Furthermore, we expect that the collected SSS data will represent a valuable tool for the calibration and validation of recent satellite observations provided by SMOS and Aquarius missions.
\end{abstract}




\section{Introduction}

The salinity of the ocean is one of the key parameters identified by the Global Climate Observing System (GCOS) as being essential for climate studies (World Meteorological Organization, 2016). Many water masses are identified and traced through salinity and temperature values; in addition, the entire ocean circulation from surface to deep layers is largely conditioned by their influence on the density field (e.g., Rahmstorf, 2006; Helm et al., 2010; Sansiviero et al., 2017). Increasing efforts have been made in the past decades to provide a global synoptic monitoring of the sea surface salinity (SSS) in conjunction with the recent launch of two dedicated satellite missions, i.e., soil moisture and ocean salinity (SMOS) in 2009 (Kerr et al., 2010) and Aquarius in 2011 (Le Vine et al., 2010). The delivered remotely sensed data provided interesting insights into the upper ocean, especially when considering that the surface layer is strictly connected to (i) the physical and biogeochemical interactions between ocean and atmosphere and (ii) the observation of large-scale circulation features (i.e., fronts, currents) as well as mesoscale and small-scale structures (i.e., meanders, eddies) (e.g., in the open ocean: Cotroneo et al., 2013; Reul et al., 2014; Ansorge et al., 2015; D'Addezio and Subrahmanyam, 2016; in marginal seas: Cotroneo et al., 2015; Rivaro et al., 2017; Mangoni et al., 2017; Misic et al., 2017; Aulicino et al., 2018a). Nevertheless, original SMOS and Aquarius products showed limitations in completely retrieving reliable SSS values in some regions of the worldwide oceans, especially at latitudes higher than $45-50^{\circ}$ (Tang et al., 2014; Kohler et al., 2015). Despite their oceanographic and biological importance, the southern sector of the Atlantic Ocean and the Southern Ocean are among such areas. It is recognized by the scientific community that further studies are needed to improve the satellite calibration, SSS retrievals algorithms, and better validate them in these regions (Lagerloef et al., 2009; Chen et al., 2014; Boutin et al., 2016). To this aim, all the available near-surface measurements (mostly in the upper $5 \mathrm{~m}$ ) can provide a significant contribution and should be shared by the oceanographic community.

Since 2010, South Africa's Department of Environmental Affairs (DEA), the South African National Antarctic Programme (SANAP), and the University of Cape Town (UCT) have carried out annual research cruises across the Southern Ocean, as part of the South Atlantic Meridional Overturning Circulation - South Africa (SAMOC-SA) program (Ansorge et al., 2014), in order to collect multidisciplinary meteo-oceanographic in situ data.

In this paper, "thermosalinograph" (hereafter TSG) data and bottle samples used for their validation are described in Sect. 2, as well as the applied quality control (QC) methodology. Then, Sect. 3 presents the comparison between the TSG SSS dataset and the other reference datasets. Finally, data record details and conclusions are reported in Sect. 4.

\section{Data and methods}

We present here the dataset collected by South African icebreakers S.A. Agulhas-I and S.A. Agulhas-II during several research cruises in the southern Atlantic Ocean and in the adjacent Southern Ocean sector between December 2010 and February 2017 (Table 1; Fig. 2).

TSGs mounted on board the two research vessels provided high-resolution measurements (conductivity, temperature, salinity) along the cruise tracks. The TSG system (Fig. 1) is a continuous, underway monitoring system connected to a dedicated scientific seawater supply. A conductivity cell measures the conductivity of the seawater pumped in, from which salinity can be deducted, while a thermistor cell measures the sea surface temperature (SST). An additional temperature sensor is installed across from the hull water inlet for measuring the actual sea surface temperature (SSTH) before it is slightly modified during the seawater path to the conductivity cell. The measuring system is similar on both vessels, with the water inlet sitting at about $5.0 \mathrm{~m}$ below the waterline. The nominal accuracy of Sea-Bird TSG SSS is better than 0.01 on the practical salinity scale (PSS), while the resolution is close to 0.001 (www.seabird.com, last access: 29 May 2018); these values are largely sufficient to capture the surface variability (Gaillard et al., 2015). These sensors are regularly calibrated and continuously monitored in-between cruises, and no appreciable sensor drift emerged in the study period. Regular comparisons between bottle samples and continuous measurements are also carried out on board during each scientific voyage. However, several aspects could increase the nominal errors and corrupt the data acquired during part of a cruise, i.e., insufficient flow through the conductivity cell, the presence of air bubbles in the pipe, or fouling contamination. Thus an accurate QC of the collected dataset, as well as an eventual comparison with external observations, are strongly recommended; these aspects will be addressed in this section and in Sect. 3, respectively. Furthermore, it is important to remark that the S.A. Agulhas-I and S.A. Agulhas-II TSG systems are generally switched on underway; however, when sailing south of $55^{\circ} \mathrm{S}$ the presence of sea ice could block the scientific water supply, repeatedly, hampering data collection. For this reason, the TSG pumps are turned off before entering the ice field in order to reduce the potential damage to the TSG system and the possible acquisition of bad data.

For each cruise, the full-resolution TSG dataset has been processed and undersampled with a median filter over a $1 \mathrm{~min}$ interval. The dataset is available at https://doi.org/10.7289/ V56M3545. We plan to provide updates as soon as further observations are collected and processed. This archive includes the following variables: time of the acquisition, latitude, longitude, conductivity, SSS, SST, SST at hull (SSTH), and sea ice flag. It is important to remark that SSS is the actual ocean salinity only if the flow rate to the conductivity cell is sufficient; otherwise, it would represent the salinity of 
Table 1. List of scientific cruises between 2010 and 2017 included in the dataset.

\begin{tabular}{llllll}
\hline Cruise name & Ship & Start date & End date & Latitude & Longitude \\
\hline SANAE 2010 & Agulhas-I & 8 Dec 2010 & 10 Feb 2011 & $33.96-70.65^{\circ} \mathrm{S}$ & $37.00^{\circ} \mathrm{W}-15.99^{\circ} \mathrm{E}$ \\
SANAE 2011 & Agulhas-I & 10 Dec 2011 & 8 Feb 2012 & $37.62-70.46^{\circ} \mathrm{S}$ & $36.51^{\circ} \mathrm{W}-11.92^{\circ} \mathrm{E}$ \\
Winter 2012 & Agulhas-II & 9 Jul 2012 & 1 Aug 2012 & $33.87-57.16^{\circ} \mathrm{S}$ & $0.00-43.07^{\circ} \mathrm{E}$ \\
Gough 2012 & Agulhas-II & 6 Sep 2012 & 10 Oct 2012 & $33.92-50.25^{\circ} \mathrm{S}$ & $15.00^{\circ} \mathrm{W}-18.09^{\circ} \mathrm{E}$ \\
SANAE 2012 & Agulhas-II & 7 Dec 2012 & 19 Feb 2013 & $33.88-70.80^{\circ} \mathrm{S}$ & $35.77^{\circ} \mathrm{W}-18.69^{\circ} \mathrm{E}$ \\
Marion 2013 & Agulhas-II & 10 Apr 2013 & 16 May 2013 & $33.88-47.79^{\circ} \mathrm{S}$ & $18.22-43.23^{\circ} \mathrm{E}$ \\
Gough 2013 & Agulhas-II & 5 Sep 2013 & 12 Sep 2013 & $34.06-37.06^{\circ} \mathrm{S}$ & $11.89^{\circ} \mathrm{W}-18.14^{\circ} \mathrm{E}$ \\
Marion 2014 & Agulhas-II & 2 Apr 2014 & 6 May 2014 & $33.88-58.75^{\circ} \mathrm{S}$ & $18.25-38.75^{\circ} \mathrm{E}$ \\
Gough 2014 & Agulhas-II & 4 Sep 2014 & 7 Oct 2014 & $33.87-49.26^{\circ} \mathrm{S}$ & $11.01^{\circ} \mathrm{W}-18.60^{\circ} \mathrm{E}$ \\
SANAE 2014 & Agulhas-II & 5 Dec 2014 & 16 Feb 2015 & $33.91-70.77^{\circ} \mathrm{S}$ & $35.31^{\circ} \mathrm{W}-17.48^{\circ} \mathrm{E}$ \\
Marion 2015 & Agulhas-II & 9 Apr 2015 & 15 May 2015 & $34.44-47.75^{\circ} \mathrm{S}$ & $18.35-39.37^{\circ} \mathrm{E}$ \\
Winter 2015 & Agulhas-II & 23 Jul 2015 & 14 Aug 2015 & $33.88-56.81^{\circ} \mathrm{S}$ & $0.00-18.64^{\circ} \mathrm{E}$ \\
Gough 2015 & Agulhas-II & 4 Sep 2015 & 6 Oct 2015 & $33.90-47.73^{\circ} \mathrm{S}$ & $11.72^{\circ} \mathrm{W}-18.61^{\circ} \mathrm{E}$ \\
SANAE 2015 & Agulhas-II & 5 Dec 2015 & 10 Feb 2016 & $34.44-70.78^{\circ} \mathrm{S}$ & $35.62^{\circ} \mathrm{W}-17.72^{\circ} \mathrm{E}$ \\
Marion 2016 & Agulhas-II & 8 Apr 2016 & 16 May 2016 & $33.87-47.77^{\circ} \mathrm{S}$ & $18.25-38.75^{\circ} \mathrm{E}$ \\
Winter 2016 & Agulhas-II & 5 Jul 2016 & 27 Jul 2016 & $33.35-55.11^{\circ} \mathrm{S}$ & $0.00-29.26^{\circ} \mathrm{E}$ \\
SANAE 2016 & Agulhas-II & 30 Nov 2016 & 2 Feb 2017 & $34.05-70.78^{\circ} \mathrm{S}$ & $33.80^{\circ} \mathrm{W}-17.64^{\circ} \mathrm{E}$ \\
\hline
\end{tabular}

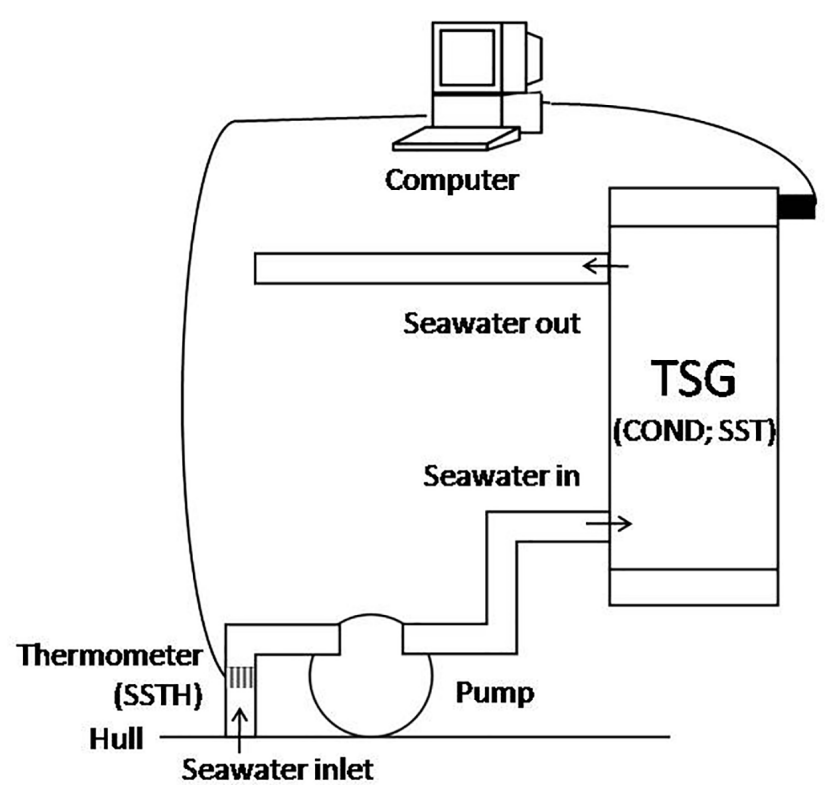

Figure 1. Schematic of the underway data collection system highlighting the seawater path to the conductivity and thermistor cells (TSG), and the temperature sensor location at the water inlet.

the seawater trapped in the TSG. As for temperatures, please note that SST is the temperature of the water volume inside the conductivity cell (TSG) while SSTH is the temperature of the ocean at the water intake very close to the hull. Monitoring SST is necessary to ensure a precise salinity, while SSTH is essential for computing actual seawater density. These values can be slightly different because of heat exchanges along the seawater path to reach the TSG. Exchanges depend on the flow rate, the volume of water in the circuit, and on the

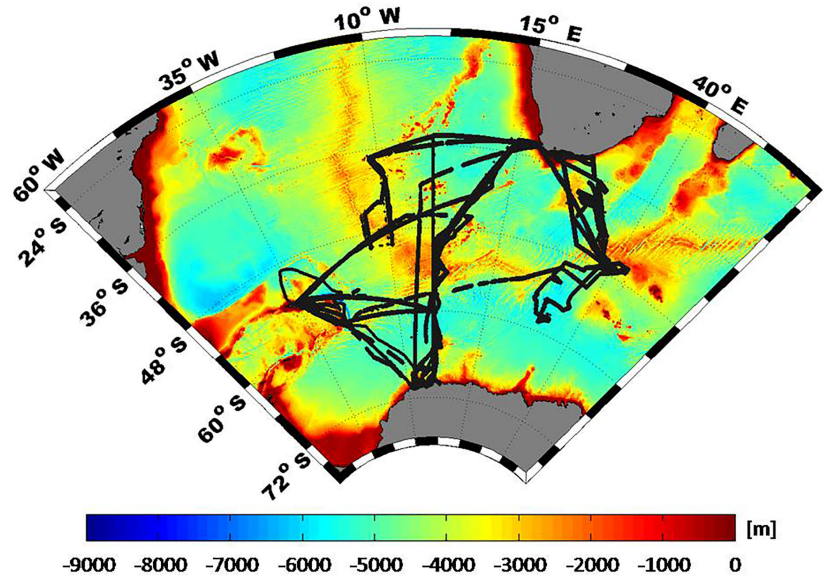

Figure 2. S.A. Agulhas-I and S.A. Agulhas-II cruise tracks (black dots) in the southern Atlantic Ocean and in the Southern Ocean between December 2010 and February 2017. Bathymetry (m) is expressed in color.

temperature difference between the seawater and the ambient temperature (Gaillard et al., 2015).

\subsection{Quality control}

The QC of the collected TSG measurements included three main steps, which led us to discard about $36 \%$ of acquired observations; statistics are summarized in Table 2. Firstly, an automatic detection of unreliable values was performed using selected threshold criteria on conductivity $\left(2.5-5.5 \mathrm{~S} \mathrm{~m}^{-1}\right)$, SSS (32.0-37.0), and SST values (varying with latitude and season) (QC-1). Then, following the World Ocean Circulation Experiment (WOCE) principles and NOAA National 
Table 2. Statistics of the quality control.

\begin{tabular}{lrr}
\hline Total measurements & 929801 & \\
\hline Discarded data after QC-1 & 242488 & $26.0 \%$ \\
Discarded data after QC-2 & 316391 & $34.0 \%$ \\
Discarded data after QC-3 & 334687 & $35.9 \%$ \\
\hline Valid SSS measurements & 595114 & \\
\hline Sea ice flagged data & 45063 & $7.5 \%$ \\
Missing COND and SST values & 51275 & $8.6 \%$ \\
Missing SSTH values & 82527 & $13.8 \%$ \\
\hline
\end{tabular}

Center for Environmental Information (NCEI) database requirements, quality flags (good, suspicious, bad, harbour, icefield) were attributed to the data based on the analysis of several factors, i.e., the detection of insufficient seawater flow, the contamination by air bubbles, and the presence of sea ice (QC-2). The episodic reductions in seawater flow were identified on the basis of a large and increasing difference between SST and SSTH, while SSS remains nearly constant; a threshold difference of $0.2^{\circ} \mathrm{C}$ was used for recognizing bad data (Gaillard et al., 2015). The analysis of the conductivity measurements pointed out the presence of episodic quick decreases to underestimated, and often unreliable, values; of course, this is also reflected in SSS, with variations that range between a few decimal places and several units on the PSS. This phenomenon is due to the presence of air bubbles in the conductivity cell usually associated with strong waves and severe sea conditions. The effect of air bubbles usually runs out in a few minutes. Measurements showing evidence of this conductivity (salinity) decrease were flagged as bad data. Furthermore, information included in the cruise reports was carefully analyzed to be aware of these events and other suspicious malfunctioning of the system. Harbor data and observations collected when sailing into ice fields were also flagged at this step (taking advantage of latitude and/or longitude information provided by cruise reports), and discarded similarly to all the other bad data.

Finally, a visual inspection of individual campaigns was carried out (QC-3), with a specific attention to data flagged as suspicious in the QC-2. An additional $2 \%$ of bad measurements were discarded, while suspicious values passing this analysis were set to good. Nevertheless, a sea ice flag was included in the dataset for identifying valid measurements that could have been slightly affected by scattered sea ice contamination, as recorded by cruise reports, when sailing the Southern Ocean. Sea ice maps retrieved through satellite passive microwave sensors (Spreen et al., 2008; Aulicino et al., 2013, 2014); synthetic aperture radar (SAR), when available, (Wadhams et al., 2016, 2018), and thermal infrared imagery (Aulicino et al., 2018b) were used for confirming ice field locations. However, when not discarded, these flagged data do not seem to significantly affect the good agreement

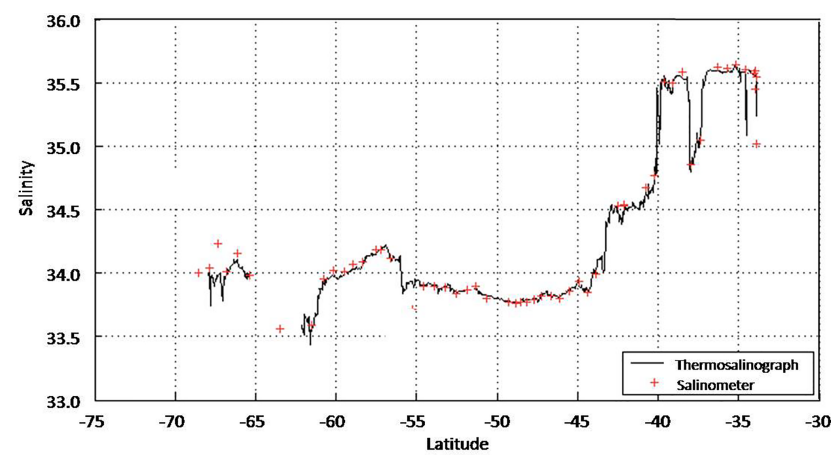

Figure 3. A comparison between TSG underway SSS (black line) collected during the southward leg of the SANAE 2012 cruise and the related bottle samples measured via the Portasal salinometer (red crosses).

between the provided TSG dataset and several independent SSS products (see Sect. 3).

It is important to note that some of the conductivity, SST, and SSTH values associated with the published SSS measurements are missing (Table 2). We inform the user that the QC-2 described above was not complete for these values, whereas an in-depth visual inspection was performed.

\subsection{Validation versus bottle samples}

During all S.A. Agulhas-I and S.A. Agulhas-II research voyages, ship-based scientific teams collected salinity samples from the uncontaminated underway lab supply usually at each 20-30 nautical miles. These samples were taken in $250 \mathrm{~mL}$ double-cap glass bottles with rubber stoppers and completely filled to minimize evaporative error. In most cases, these independent water samples were analyzed directly on board with a Portasal salinometer $8410 \mathrm{~A}$ in order to get a potential reference for adjusting the TSG data. Triple Portasal measures of each sample (then averaging) were usually performed on bottle samples to reduce possible errors. During some cruises salinity samples were not analyzed on board but later, due to severe weather conditions. Actually, no systematic bias was found, thus no adjustment to TSG measurements was necessary. Figure 3 shows an example of the comparison between the TSG data and the bottled samples analyzed with the Portasal during the southward leg of the SANAE 2012 cruise. Only few outliers are present at the start and, mostly, at the end of this leg. The offset between TSG and Portasal salinity values is plotted in Fig. 4; the average standard deviation, correcting for the outlier, would result in a $p<0.01$. Similar results were found for the other cruises. A compilation of these results is provided in Fig. 5 in order to better assess the quality of the whole dataset. The mean and standard deviation of the difference between TSG measurements and bottle samples per $\left(1^{\circ}\right)$ latitudinal $1^{\circ}$ bin are reported. Although a different number of samples was processed for each latitudinal bin (much more data were 
Table 3. Name and description of the main variables included in the TSG NetCDF files.

\begin{tabular}{lll}
\hline Name of variable & Unit & Description \\
\hline TIME & dd/mm/yyyyhh:mm & Date and time of TSG measurement \\
LAT & decimal degree & Latitude of TSG measurement \\
LON & decimal degree & Longitude of TSG measurement \\
COND & Siemens per meter & TSG conductivity measurement \\
SSS & - & Salinity retrieved from SST and COND \\
SST & degrees Celsius & TSG temperature measurement \\
SSTH & degrees Celsius & Temperature measurement at hull \\
SEA ICE & $0-1$ & Sea ice flag $0=$ no ice, $1=$ scatter ice \\
\hline
\end{tabular}

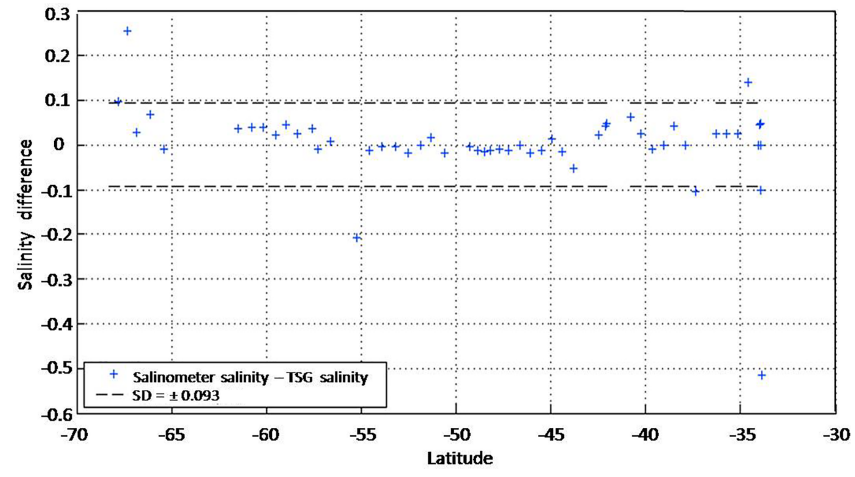

Figure 4. A diagram showing the difference in salinity between the TSG and the Portasal salinometer during the southward leg of the SANAE 2012 cruise. Standard deviation value (SD) is reported in the legend.

collected north of $48^{\circ} \mathrm{S}$ ), an overall general agreement was found with evident outliers identified only at 55 and $61^{\circ} \mathrm{S}$. This is most likely due to careful maintenance of the TSG on board the S.A. Agulhas-I and S.A. Agulhas-II provided by the scientific teams, including cleaning of the tank, pump, and conductivity cell at the beginning of each cruise; stopping the TSG when entering the ice field; and constant monitoring of possible bio-fouling during the cruise.

\section{Comparison of TSG sea surface salinities to other reference datasets}

For a general assessment of our measurements, the TSG SSS dataset was compared to several global gridded reference SSS datasets over the southern Atlantic and the adjacent sectors of the Southern Ocean covered by the South African cruises. The reference datasets, which do not include South African TSG information, are the following: (i) the World Ocean Atlas 2013 (WOA13), (ii) the Global ARMOR3D L4 products, and (iii) the GLORYS ocean reanalysis. A pointto-point comparison with Argo measurements was also attempted, but the very low number of co-located observations was considered insufficient.

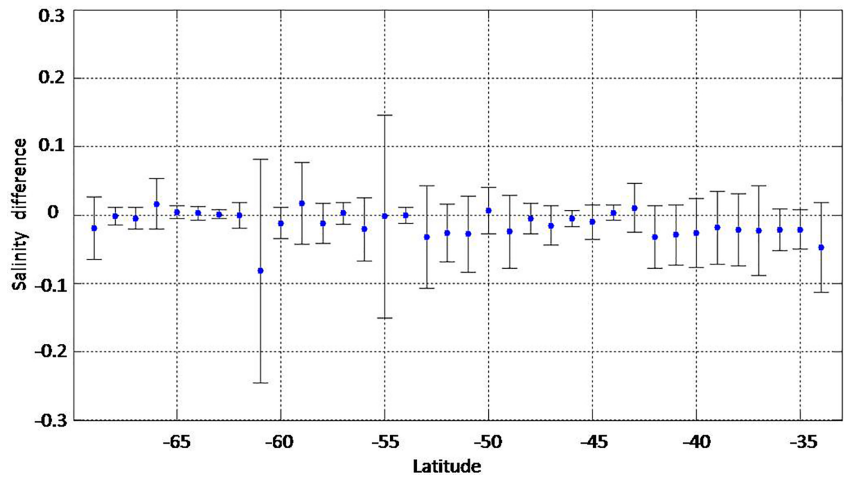

Figure 5. Mean (blue dots) and standard deviation (gray bars) values of difference in salinity between the TSG and the Portasal salinometer per latitudinal $1^{\circ}$ bin for the 2010-2017 dataset.

WOA13 is a long-term set of objectively analyzed climatologies at annual, seasonal, and monthly timescales produced by the National Oceanic and Atmospheric Administration's National Oceanographic Data Center (NOAA-NODC). We used monthly composite salinity fields on a $0.25^{\circ}$ grid (Zweng et al., 2013) for a comparison with our TSG SSS data. All WOA13 climatological mean fields are available on the NODC website (www.nodc.noaa.gov) in NetCDF as well as other common file formats. ARMOR3D is a monthly objective reanalysis that includes salinity on a $0.25^{\circ}$ regular grid on 33 depth levels (also at a weekly period in V4). ARMOR L4 products are obtained by assimilating satellite and in situ observations through statistical methods around a climatology. In particular, the ARMOR3D temperaturesalinity $(T / S)$ combined fields are generated using a two step procedure: synthetic fields are obtained from sea level anomalies and SST satellite information projected onto the vertical using a multiple linear regression method and the covariances deduced from historical observations; then, the synthetic fields and all available in situ $T / S$ profiles (including Argo and CTD profiles) are combined through an optimal interpolation method (Guinehut et al., 2012). ARMOR3D data are available through the Copernicus online catalogue (http://marine.copernicus.eu/). GLORYS (V4) is a 

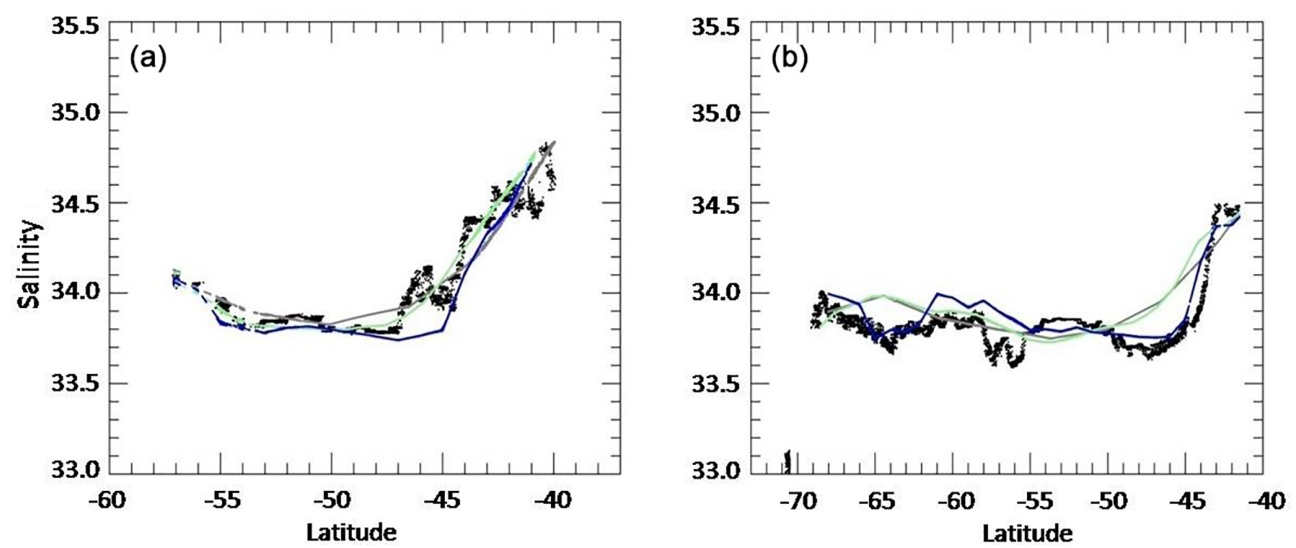

Figure 6. A comparison between TSG SSS (black dots) and monthly gridded products from WOA13 (gray), ARMOR3D (green), and GLORYS (blue) gridded salinities during July 2012 (a) and February 2013 (b) for S.A. Agulhas-II scientific cruises.

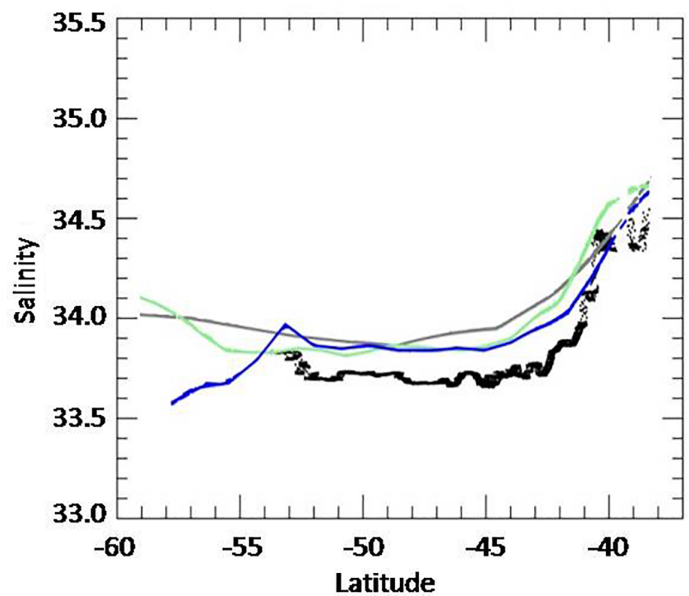

Figure 7. A comparison between TSG SSS (black) and monthly gridded products from WOA13 (gray), ARMOR3D (green), and GLORYS (blue) gridded salinities during December 2015 for S.A. Agulhas-II scientific cruises showing a large negative bias between transect and gridded data over Antarctic waters which is solidly supported by bottles validation.

reanalysis project carried out in the framework of the Copernicus Marine Environment Monitoring Service (CMEMS), which produces and distributes daily global ocean reanalysis on 75 levels at eddy permitting resolution $\left(0.25^{\circ}\right)$. Salinity products are generated through the assimilation (based on a reduced order Kalman filter) of in situ $T / S$ observations (including also $T$ / $S$ profiles collected by sea mammals) using the NEMO dynamical ocean model in the ORCA025 configuration (Ferry et al., 2015). Data are available through the Copernicus online catalogue.

The TSG SSS dataset showed generally good agreement to the ensemble of reference datasets (WOA13, ARMOR, and GLORYS), with absolute biases generally lower than 0.1 and well within the level of spread found among the references themselves. A compilation of the statistical results is reported in Table 4. We were aware that differences due to the smallscale variability filtered out by the gridded products could emerge when comparing local measurements to larger-scale and monthly-averaged salinity fields. However, even though instances where transect data deviate from the reference ensemble were identified, overall local differences were lower than expected. The standard deviation of the local differences is between 0.1 and 0.2 and likely corresponds to mesoscale variability. The austral winter and summer examples reported in Fig. 6 show that TSG salinities agree well with gridded references regardless of the season; on the other hand, they suggest that the level of agreement changes with latitude in the study region. In the sub-Antarctic waters, TSG SSS follows very well the large-scale signature of the salinity fronts featured in the gridded products; some deviations are present, presumably related to actual salinity mesoscale and sub-mesoscale structures that the monthly maps cannot resolve. When approaching Antarctic waters and the sea ice edge, larger spreads from reference products can be found; but most of the significant deviations disappear when masking the sea ice flagged SSS values in the transect data (as in Fig. 6). These differences can be ascribed to the presence of scattered sea ice, which may influence SSS and/or could affect the TSG nominal functioning due to the presence of ice crystals (e.g., causing seawater flux to slow down or temporary interruption); but could also be due to the sparseness of in situ observations at high latitudes in the gridded products. Of particular relevance are the larger biases found between the TSG SSS and the reference datasets later in 2015 (Fig. 7), revealing a signature of surface freshening possibly associated with the low Antarctic sea ice extent anomaly of 2016, which the gridded references apparently fail to detect. In this case, the freshening signature captured in the TSG SSS is effectively supported by bottle validation, lending it further credibility. 
Table 4. Compilation of the statistical results (bias and SD) obtained through the analysis of the difference between reference salinities (i.e., WOA09, ARMOR, GLORYS) and TSG salinities, for each transect of the analyzed research cruises. The comparison is limited to the end of 2015 , i.e., the last available year with complete reanalysis data for the reference datasets.

\begin{tabular}{|c|c|c|c|c|c|c|c|}
\hline \multirow[t]{2}{*}{ Cruise } & \multirow[t]{2}{*}{ Dates year_month_dd-dd } & Bias & SD & Bias & SD & Bias & SD \\
\hline & & \multicolumn{2}{|c|}{ WOA09 } & \multicolumn{2}{|c|}{ ARMOR } & \multicolumn{2}{|c|}{ GLORYS } \\
\hline SANAE 2010 & 2010_12_11-22 & 0.07 & 0.10 & 0.07 & 0.12 & -0.09 & 0.14 \\
\hline SANAE 2010 & 2011_01_04-12 & -0.11 & 0.12 & -0.16 & 0.14 & -0.36 & 0.23 \\
\hline SANAE 2010 & 2011_01_12-23 & -0.11 & 0.09 & -0.14 & 0.10 & -0.37 & 0.19 \\
\hline SANAE 2011 & 2012_01_03-18 & 0.46 & 0.19 & 0.45 & 0.17 & 0.20 & 0.29 \\
\hline SANAE 2011 & 2012_01_18-25 & 0.26 & 0.30 & 0.25 & 0.27 & 0.05 & 0.26 \\
\hline Winter 2012 & 2012_07_15-23 & $<0.01$ & 0.09 & $<0.01$ & 0.08 & -0.08 & 0.10 \\
\hline Winter 2012 & 2012_07_23-03 & 0.08 & 0.17 & 0.05 & 0.15 & $<0.01$ & 0.13 \\
\hline Gough 2012 & 2012_09_21-25 & -0.04 & 0.20 & -0.03 & 0.20 & -0.05 & 0.16 \\
\hline Gough 2012 & 2012_09_25-29 & -0.06 & 0.14 & -0.08 & 0.20 & -0.12 & 0.18 \\
\hline SANAE 2012 & 2012_12_11-28 & 0.03 & 0.13 & 0.02 & 0.12 & -0.03 & 0.10 \\
\hline SANAE 2012 & 2013_01_16-25 & 0.12 & 0.18 & 0.08 & 0.18 & 0.05 & 0.21 \\
\hline SANAE 2012 & 2013_01_25-31 & 0.04 & 0.13 & 0.01 & 0.14 & 0.07 & 0.18 \\
\hline SANAE 2012 & 2013_02_01-18 & 0.09 & 0.12 & 0.09 & 0.13 & 0.06 & 0.09 \\
\hline Marion 2014 & 2014_04_07-19 & 0.02 & 0.13 & -0.01 & 0.14 & -0.01 & 0.12 \\
\hline Marion 2014 & 2014_04_19-05 & 0.07 & 0.13 & $<0.01$ & 0.15 & 0.01 & 0.13 \\
\hline SANAE 2014 & 2014_12_07-17 & 0.06 & 0.12 & 0.03 & 0.15 & 0.09 & 0.14 \\
\hline SANAE 2014 & 2014_12_30-15 & 0.22 & 0.17 & 0.20 & 0.17 & 0.09 & 0.18 \\
\hline SANAE 2014 & 2015_01_15-22 & 0.15 & 0.13 & 0.07 & 0.15 & 0.05 & 0.17 \\
\hline SANAE 2014 & 2015_02_09-17 & 0.12 & 0.24 & 0.15 & 0.16 & 0.09 & 0.17 \\
\hline Winter 2015 & 2015_07_29-06 & 0.13 & 0.08 & 0.08 & 0.09 & 0.02 & 0.08 \\
\hline Winter 2015 & 2015_08_06-10 & 0.16 & 0.09 & 0.15 & 0.12 & 0.09 & 0.05 \\
\hline SANAE 2015 & 2015_12_10-15 & 0.19 & 0.11 & 0.17 & 0.08 & 0.12 & 0.10 \\
\hline SANAE 2015 & 2015_12_27-08 & 0.19 & 0.11 & 0.13 & 0.11 & 0.07 & 0.11 \\
\hline
\end{tabular}

Furthermore, several interesting geophysical features can be identified and analyzed through the TSG dataset. Among others, the presence of sharp gradients in proximity to the Antarctic Circumpolar Current (ACC) fronts is really evident. A coupled analysis of TSG SSS and expendable bathythermograph (XBT) observations collected along each cruise could be attempted for monitoring front locations and variability, and eventually analyze transport and variability in the ACC south of Africa (Swart et al., 2008), also in the perspective of climate change (Bard and Rickaby, 2009; Beal et al., 2011). Then, TSG data collected in proximity to the Agulhas current and its retroflection could be very useful for studying the current fluctuations and the eventual presence of pulses and rings (Swart and Speich, 2010).

\section{Data availability}

TSG data are available to the public in text format through an unrestricted repository at https://doi.org/10.7289/ V56M3545. Table 3 summarizes the main variables, while the metadata are included in the "readme" file provided with data on the NOAA-NCEI archive. One file is created for each research cruise. The naming convention is code_yyyy.txt, where code is a cruise type identification name depending on the cruise objective or enquired area, i.e., SANAE, WINTER, MARION, GOUGH; and yyyy is the year when TSG acquisition started.

\section{Data records and conclusions}

We believe that this exceptional SSS dataset represents a valuable source of high-resolution, independent, and reliable information capable of completing data collected through the existing observing networks (i.e., drifters, ARGO floats, glider fleets), and current state-of-the-art gridded salinity products. A sea ice flag helps with its correct use south of the Antarctic polar front. The final goal is enlarging the amount of in situ ocean observations available to the scientific community for addressing several climatic issues. In particular, improving the knowledge of sea surface thermohaline features is one of the most important results to be achieved for advancing studies focusing on climate variability in the Southern Hemisphere. Although the Southern Ocean is a key place for atmosphere-ocean interactions at different spatial and temporal scales (Cerrone et al., 2017a, b; Buongiorno Nardelli et al., 2017; Fusco et al., 2018), mesoscale and submesoscale processes acting in the Atlantic sector are still poorly known because of the limited number of available 
in situ measurements and the coarse accuracy/resolution of the available SSS satellite observations (Boutin et al., 2016). That is particularly true of the ACC region and its fronts, which are characterized by complex dynamics and intense eddy activity (Cotroneo et al., 2013; Frenger et al., 2015). Furthermore, even though causes have not been firmly defined, several studies pointed out that recent salinity changes in the Southern Ocean are among the most prominent signals of climate change in the global Ocean (Böning et al., 2008; Haumann et al., 2016); the freshening signature captured in our TSG SSS could contribute to this debate (Boutin et al., 2013).

In this framework, even though limited in time (i.e., few months per year) and space (i.e., the Atlantic sector of the Southern Ocean), the present TSG SSS dataset represents an uncommon opportunity to partially fill this lack of information, and a valuable tool for improving the reconstruction of density fields in combination with numerical simulations (Chen et al., 2017) and the calibration and validation of SSS satellite observations recently provided by SMOS and Aquarius missions.

Author contributions. GA and YC conceived and designed the manuscript. GA, YC, IA and MvdB collected the measurements and organized the TSG dataset. GA and CC carried out the quality control analyses and the validation of the TSG measurements versus the bottle samples. MBR and EOC performed the comparison of TSG salinities to other reference dataset. All authors analyzed the achieved results, contributed to the writing, and approved the final manuscript.

Competing interests. The authors declare that they have no conflict of interest.

Acknowledgements. We acknowledge the support of the Department of Environmental Affairs (DEA), South Africa; the South African National Antarctic Programme (SANAP), South Africa; and the Italian National Antarctic Research Programme (PNRA), Italy. This study was made possible thanks to the contribution of the Southern Ocean Chokepoint: an Italian Contribution (SO-ChIC) project and the Multiplatform Observations and Modeling in a sector of the Antarctic circumpolar current (MOMA) project. Special thanks go to the captain, officers, and crew of the S.A. Agulhas-I and $I I$ as well as all the technicians, scientists, and students on board the S.A. Agulhas-I and S.A. Agulhas-II research vessels who contributed to the TSG data functioning and cleaning, and to the onboard SSS validation activities.

Edited by: Giuseppe M. R. Manzella

Reviewed by: one anonymous referee

\section{References}

Ansorge, I., Baringer, M. O., Campos, E. J. D., Dong, S., Fine, R. A., Garzoli, S. L., Goni, G., Meinen, C. S., Perez, R. C., Piola, A. R., Roberts, M. J., Speich, S., Sprintall, J., Terre, T., and van den Berg, M. A.: Basin-wide oceanographic array bridges the South Atlantic, Eos T. Am. Geophys. Un., 95, 53-54, 2014.

Ansorge, I., Jackson, J., Reid, K., Durgadoo, J., Swart, S., and Eberenz, S.: Evidence of a southward eddy corridor in the southwest Indian Ocean, Deep-Sea Res. Pt. II, 119, 69-76, 2015.

Aulicino, G., Fusco, G., Kern, S., and Budillon, G.: 1992-2011 sea ice thickness estimation in the Ross and Weddell Seas from SSM/I brightness temperatures, European Space Agency, Special Publication ESA SP-712, 2013.

Aulicino, G., Fusco, G., Kern, S., and Budillon, G.: Estimation of sea ice thickness in Ross and Weddell Seas from SSM/I brightness temperatures, IEEE T. Geosci. Remote, 52, 4122-4140, 2014.

Aulicino, G., Cotroneo, Y., Ruiz, S., Sánchez Román, A., Pascual, A., Fusco, G., Tintoré, J., and Budillon, G.: Monitoring the Algerian Basin through glider observations, satellite altimetry and numerical simulations along a SARAL/AltiKa track, J. Marine Syst., 179, 55-71, 2018a.

Aulicino, G., Sansiviero, M., Paul, S., Cesarano, C., Fusco, G., Wadhams, P., and Budillon, G.: A new approach for monitoring the Terra Nova Bay polynya through MODIS ice surface temperature imagery and its validation during 2010 and 2011 winter seasons, Remote Sens., 10, 366, https://doi.org/10.3390/rs10030366, 2018b.

Bard, E. and Rickaby, R. E. M.: Migration of the subtropical front as a modulator of glacial climate, Nature, 460, 380-383, 2009.

Beal, L. M., De Ruijter, W. P., Biastoch, A., Zahn, R., and SCOR/WCRP/IAPSO Working Group 13: On the role of the Agulhas system in ocean circulation and climate, Nature, 472, 429436, 2011.

Böning, C. W., Dispert, A., Visbeck, M., Rintoul, S. R., and Schwarzkopf, F. U.: The response of the Antarctic Circumpolar Current to recent climate change, Nat. Geosci., 1, 864-869, 2008.

Boutin, J., Martin, N., Reverdin, G., Yin, X., and Gaillard, F.: Sea surface freshening inferred from SMOS and ARGO salinity: impact of rain, Ocean Sci., 9, 183-192, https://doi.org/10.5194/os9-183-2013, 2013.

Boutin, J., Chao, Y., Asher, W. E., Delcroix, T., Drucker, R., Drushka, K., Kolodziejczyk, N., Lee, T., Reul, N., Reverdin, G., Schanze, J., Soloviev, A., Yu, L., Anderson, J., Brucker, L., Dinnat, E., Santos-Garcia, A., Jones, W. L. Maes, C., Meissner, T., Tang, W., Vinogradova, N., and Ward, B.: Satellite and in situ salinity: Understanding near-surface stratification and subfootprint variability, B. Am. Meteorol. Soc., 97, 1391-1407, 2016.

Buongiorno Nardelli, B., Guinehut, S., Verbrugge, N., Cotroneo, Y., Zambianchi, E., and Iudicone, D.: Southern Ocean mixed-layer seasonal and interannual variations from combined satellite and in situ data, J. Geophys. Res., 122, 10042-10060, 2017.

Cerrone, D., Fusco, G., Simmonds, I., Aulicino, G., and Budillon, G.: Dominant covarying climate signals in the Southern Ocean and Antarctic sea ice influence during the last three decades, J. Climate, 30, 3055-3072, 2017a. 
Cerrone, D., Fusco, G., Cotroneo, Y., Simmonds, I., and Budillon, G.: The Antarctic Circumpolar Wave: Its presence and interdecadal changes during the last 142 years, J. Climate, 30, 63716389, 2017b.

Chen, J., Zhang, R., Wang, H., Yuzhu, A., An, Y., Wang, L., and Wang, G.: An analysis on the error structure and mechanism of soil moisture and ocean salinity remotely sensed sea surface salinity products, Acta Oceanol. Sin., 33, 48-55, 2014.

Chen, J., You, X., Xiao, Y., Zhang, R., Wang, G., and Bao, S.: A performance evaluation of remotely sensed sea surface salinity products in combination with other surface measurements in reconstructing three-dimensional salinity fields, Acta Oceanol. Sin., 36, 15-31, 2017.

Cotroneo, Y., Budillon, G., Fusco, G., and Spezie, G.: Cold core eddies and fronts of the Antarctic Circumpolar Current south of New Zealand from in situ and satellite data, J. Geophys. Res.Oceans, 118, 2653-2666, 2013.

Cotroneo, Y., Aulicino, G., Ruiz, S., Pascual, A., Budillon, G., Fusco, G., and Tintoré, J.: Glider and satellite high resolution monitoring of a mesoscale eddy in the Algerian basin: effects on the mixed layer depth and biochemistry, J. Marine Syst., 162, 73-88, 2015.

D'Addezio, J. M. and Subrahmanyam, B.: Sea surface salinity variability in the Agulhas Current region inferred from SMOS and Aquarius, Remote Sens. Environ., 180, 440-452, 2016.

Ferry, N., Parent, L., Masina, S., Storto, A., Haines, K., Valdivieso, M., Barnier, B., Molines, J. M., Zuo, H., and Balmaseda, M.: Product user manual for Global Ocean Reanalysis Products, CMEMS version scope: Version 1.0, Copernicus Marine Environment Monitoring Service (CMEMS), 2015.

Frenger, I., Muennich, M., Gruber, N., and Knutti, R.: Southern Ocean eddy phenomenology, J. Geophys. Res.-Oceans, 120, 7413-7449, 2015.

Fusco, G., Cotroneo, Y., and Aulicino, G.: Different behaviours of the Ross and Weddell seas surface heat fluxes in the period 19722015, Climate, 6, 17, https://doi.org/10.3390/cli6010017, 2018.

Gaillard, F., Diverres, D., Jacquin, S., Gouriou, Y., Grelet, J., Le Menn, M., Tassel, J., and Reverdin, G.: Sea surface temperature and salinity from French research vessels, 2001-2013, Scientific Data, 2, 150054, https://doi.org/10.1038/sdata.2015.54, 2015.

Guinehut, S., Dhomps, A.-L., Larnicol, G., and Le Traon, P.Y.: High resolution 3-D temperature and salinity fields derived from in situ and satellite observations, Ocean Sci., 8, 845-857, https://doi.org/10.5194/os-8-845-2012, 2012.

Haumann, F. A., Gruber, N., Münnich, M., Frenger, I., and Kern, S.: Sea-ice transport driving Southern Ocean salinity and its recent trends, Nature, 537, 89-92, 2016.

Helm, K. P., Bindoff, N. L., and Church, J. A.: Changes in the global hydrological-cycle inferred from ocean salinity, Geophys. Res. Lett., 37, L18701, https://doi.org/10.1029/2010GL044222, 2010.

Kerr, Y., Waldteufel, P., Wigneron, J. P., Delwart, S., Cabot, F., Boutin, J., Escorihuela, M. J., Font, J., Reul, N., Gruhier, C., Juglea, S., Drinkwater, M., Hahne, A., Martin-Neira, M., and Mecklenburg, S.: The SMOS mission: A new tool for monitoring key elements of the global water cycle, Proceedings of the IEEE, 98, 666-687, 2010.

Kohler, J., Sena Martins, M., Serra, N., and Stammer, D.: Quality assessment of spaceborne sea surface salinity observations over the northern North Atlantic, J. Geophys. Res.-Oceans, 120, 94$112,2015$.

Lagerloef, G., Boutin, J.,Chao, Y., Delcroix, T., Font, J., Niiler, P., Reul, N., Riser, S., Schmitt, R., Stammer, D., and Wentz, F.: Resolving the global surface salinity field and variations by blending satellite and in situ observations, in: Proceedings of OceanObs'09: Sustained Ocean Observations and Information for Society (Vol. 2), Venice, Italy, 21-25 September 2009, edited by: Hall, J., Harrison, D. E., and Stammer, D., 11 pp., 2009.

Le Vine, D., Lagerloef, G., and Torrusio, S.: Aquarius and remote sensing of sea surface salinity from space, Proceedings of the IEEE, 98, 688-703, 2010.

Mangoni, O., Saggiomo, V., Bolinesi, F., Margiotta, F., Budillon, G., Cotroneo, Y., Misic, C., Rivaro, P., and Saggiomo, M.: Phytoplankton blooms during austral summer in the Ross Sea, Antarctica: driving factors and trophic implications, PLoS ONE, 12 e0176033, https://doi.org/10.1371/journal.pone.0176033, 2017.

Misic, C., Covazzi Harriague, A., Mangoni, O., Aulicino, G., Castagno, P., and Cotroneo, Y.: Effects of physical constraints on the lability of POM during summer in the Ross Sea, J. Marine Syst., 166, 132-143, 2017.

Rahmstorf, S.: Thermohaline Ocean Circulation, in: Encyclopedia of Quaternary Sciences, edited by: Elias, S. A., Elsevier, Amsterdam, 2006.

Reul, N., Chapron, B., Lee, T., Donlon, C., Boutin, J., and Alory, G.: Sea surface salinity structure of the meandering Gulf Stream revealed by SMOS sensor, Geophys. Res. Lett., 41, 3141-3148, 2014.

Rivaro, P., Ianni, C., Langone, L., Ori, C., Aulicino, G., Cotroneo, Y., Saggiomo, M., and Mangoni, O.: Physical and biological forcing of mesoscale variability in the carbonate system of the Ross Sea (Antarctica) during summer 2014, J. Mar. Syst., 166, 144-158, 2017.

Sansiviero, M., Morales Maqueda, M. Á., Fusco, G., Aulicino, G., Flocco, D., and Budillon, G.: Modelling sea ice formation in the Terra Nova Bay polynya, J. Marine Syst., 166, 4-25, 2017.

Spreen, G., Kaleschke, L., and Heygster, G.: Sea ice remote sensing using AMSR-E 89-GHz channels, J. Geophys. Res., 113, C02S03, https://doi.org/10.1029/2005JC003384, 2008.

Swart, S. and Speich, S.: An altimetry-based gravest empirical mode south of Africa: 2. Dynamic nature of the Antarctic Circumpolar Current fronts, J. Geophys. Res., 115, C03003, https://doi.org/10.1029/2009JC005300, 2010.

Swart, S., Speich, S., Ansorge, I., Goni, G., Gladyshev, S., and Lutjeharms, J. R. E.: Transport and variability of the Antarctic Circumpolar Current south of Africa, J. Geophys. Res., 113, C09014, https://doi.org/10.1029/2007JC004223, 2008.

Tang, W., Yueh, S. H., Fore, A. G., and Hayashi, A.: Validation of Aquarius sea surface salinity with in situ measurements from Argo floats and moored buoys, J. Geophys. Res.-Oceans, 119, 6171-6189, 2014.

Wadhams, P., Aulicino, G., Parmiggiani, F., and Pignagnoli, L.: Sea ice thickness mapping in the Beaufort Sea using wave dispersion in pancake ice - a case study with intensive ground truth, European Space Agency, Special Publication ESA SP-740, 2016.

Wadhams, P., Aulicino, G., Parmiggiani, F., Persson, P. O. G., and Holt, B.: Pancake ice thickness mapping in the Beaufort Sea from wave dispersion observed in SAR 
imagery, J. Geophys. Res.-Oceans, 123, 2213-2237, https://doi.org/10.1002/2017JC013003, 2018.

World Meteorological Organization: GCOS 2016 Implementation Plan, "The Global Observing System for Climate: Implementation Needs", 2016.
Zweng, M. M, Reagan, J. R., Antonov, J. I., Locarnini, R. A., Mishonov, A. V., Boyer, T. P., Garcia, H. E., Baranova, O. K., Johnson, D. R., Seidov, D., and Biddle, M. M.: World Ocean Atlas 2013, Volume 2: Salinity, edited by: Levitus, S. and Mishonov, A., NOAA Atlas NESDIS, 74 pp., 2013. 